\title{
Clinico-Bacteriological profile \& Effect of Home remedies on Acute
} Abscess

\author{
Patel VK ${ }^{1}$, Patel $U^{2}$, Gaharwar APS ${ }^{3}$, Shrivastava GP ${ }^{4}$, Gupta R $^{5}$, Patel NP \\ ${ }^{1}$ Dr. Vishnu Kumar Patel*, Assistant Professor (Surgery), ${ }^{2}$ Dr. Umesh Patel ${ }^{\#}$, Associate Professor (Pediatrics), ${ }^{3}$ Dr. APS \\ Gaharwar*, Professor (Surgery), ${ }^{4}$ Dr. GP Shrivastava*, Professor (Surgery), ${ }^{5}$ Dr. Rachna Gupta*, Associate Professor. *All \\ are affiliated with SS Medical College, Rewa (MP), ${ }^{6}$ Dr. Narmada Prasad Patel ${ }^{\#}$, Associate Professor (Medicine), ${ }^{\#}$ Affiliated \\ with L N Medical College, Bhopal (MP), India
}

Address for Correspondence: Dr Vishnu Kumar Patel: drvishnu.patel@gmail.com

\begin{abstract}
Acute abscess are very common in tropical countries like India. We have conducted this study to evaluate clinical \& etiological profile of abscess. Design: Prospective study. Methodology: All patients with soft tissue abscesses either admitted in Surgery Department or attended Surgical OPD during the study period. Cases of small superficial abscesses managed in Out Patient Department. Data regarding the age, sex, hemoglobin, location of the abscess and cause if any, was tabulated. Results: Total 1065 cases were included in this study, $63.57 \%$ were male and 36.43\% were female. Most common age groups were between 6-20 years (22.25\% male and $10.89 \%$ female, total $33.15 \%)$ and $21-40$ years $(20.66 \%$ male and $14.02 \%$ females, total $35.31 \%$ ). $81.78 \%$ patients belonged to lower socio-economic status. Pain and swelling were the most common presenting symptoms $(99.06 \%$ and $99.15 \%$ respectively). Lower limb was the commonest site with $33.34 \%$ followed by upper limbs (23.66\%). There was high percentage $(40.46 \%)$ of pre-hospitalization home based interventions that increased the complication rate. Staphylococcus aureus was most common culprit organism in $72 \%$ cases (80 out of 111 cultures done). Causes were not known in $79.53 \%$ cases, but $7.32 \%$ cases developed abscesses after intramuscular injections. Conclusion: Soft tissue abscesses are more prevalent in lower socio-economic group and rainy season. In most of the cases, the cause is unknown; trauma and intramuscular injection are the leading underlying known causes of these abscesses. Use of home remedies had increased the complication rate.
\end{abstract}

Key words: Abscess, Soft Tissue Abscess, Bacteriological

\section{Introduction}

Infection and infectious diseases will last as long as humanity itself. Most surgical infections are result of damaged host defenses, especially injury to the epithelial barrier that normally protects the sterile internal environment from exogenous and endogenous bacteria. The most obvious example of surgical infection is an acute superficial abscess.

Skin and soft tissue abscesses involve microbial invasion of the skin and underlying soft tissues. They have variable presentations, etiologies and severities. Acute abscesses are very common in tropical countries like India and common cause of morbidity. Hot and humid climate contributes to a higher incidence [1]. Whereas certain types of abscesses are decreasing in prevalence in the western world, situation is quite

Manuscript received: $4^{\text {th }}$ Aug 2014

Reviewed: $17^{\text {th }}$ Aug 2014

Author Corrected: $26^{\text {th }}$ Aug 2014

Accepted for Publication: $17^{\text {th }}$ Sept 2014 different in most developing countries [2]. Abscesses are common presenting complaint in adult and pediatric populations. Due to poor economic condition, poor hygiene, lack of education and malnutrition, we frequently encounter these abscesses and related complications, sometimes life threatening.

With the improvement of healthcare, accessibility of the poor people to healthcare system and development of radiological imaging like USG, CT scan, MRI as diagnostic tools, incidence of complication of abscess is becoming less due to early diagnosis and interventions. Many of the smaller abscesses are treated as out-patients but with large abscesses and who were toxic need admission and were usually drained under general anesthesia.

Because many time abscesses and soft tissue infections are not cultured, most common cause generally remains 
uncertain, although staphylococcus aureus and beta hemolytic streptococci are often suggested as being the most important. The importance of soft tissue abscesses lies in the morbidity and occasional mortality. The purpose of this prospective study is to determine the current status of acute abscesses in central India in terms of distribution, predisposing factors, etiology and outcome.

\section{Aims and objectives}

1. To study the incidence of abscesses in general population.

2. To explore age and sex variation along with relationship to socioeconomic status.

3. To study clinical presentations in relation to site and nature of abscesses.

4. To study common pathogens responsible.

5. To evaluate result of treatment and complication

\section{Material and Methods}

The present study was carried out in 1065 patients, who attended surgical OPD, casualty and admitted in surgical ward of tertiary care teaching hospital in central India over a period of one year.

\section{Exclusion criteria-}

1. Deep seated visceral abscesses like liver abscess.

2. Bony abscesses.

3. Residual abscess following medical or surgical intervention.
4. Patients with known immunodeficiency conditions.

5. Abscess developed after use of cytotoxic drugs.

Clinical diagnosis of acute abscesses was made on the basis of classical symptoms and sign. The case record of all the patients was reviewed and tabulated for age, sex, occupation, socio-economic status and duration of disease. Abscesses were examined in details for number, site, size, color, local temperature, tenderness, fluctuation, discharge, overlying skin, regional lymph nodes and loss of function, predisposing cause (intramuscular injection, trauma, application of indigenous substances and hot fomentation), risk factors (diabetes mellitus, hypertension, tuberculosis and addiction).

After the clinical diagnosis was made, complete laboratory investigation done including hemoglobin, TLC, DLC, RBS, blood urea and blood culture were done in selected cases.

Incision and drainage was carried out under local or general anesthesia, depending on need. Pus was sent for culture and sensitivity test. Culture and sensitivity report $(\mathrm{C} / \mathrm{S})$ was available in 111 cases. Empirical antibiotic was started in all cases and modified later according to $\mathrm{C} / \mathrm{S}$ report if needed. Post-operative dressings were done daily.

Result of the treatment and antibiotic therapy were recorded in respect to mean healing time along with result of pus culture and sensitivity.

\section{Results}

Table No 01: Distribution of cases according to Age, Sex \& Socio-economic status (n=1065)

\begin{tabular}{|c|c|c|c|c|c|c|c|c|c|c|c|}
\hline \multirow{2}{*}{$\begin{array}{l}\text { S. } \\
\text { No }\end{array}$} & \multirow{2}{*}{$\begin{array}{c}\text { Age } \\
\text { (Years) }\end{array}$} & \multicolumn{2}{|c|}{ Male } & \multicolumn{2}{|c|}{ Female } & \multicolumn{2}{|c|}{ Total } & \multicolumn{4}{|c|}{ Socio-economic status } \\
\hline & & No & $\%$ & No & $\%$ & No & $\%$ & S. No & Class & No & $\%$ \\
\hline 1. & $0-5$ & 71 & 06.67 & 52 & 04.88 & 123 & 11.55 & \multirow[t]{2}{*}{1.} & \multirow[t]{2}{*}{ Lower } & \multirow[t]{2}{*}{871} & \multirow[t]{2}{*}{81.78} \\
\hline 2. & $6-20$ & 237 & 22.25 & 116 & 10.89 & 353 & 33.15 & & & & \\
\hline 3. & $21-40$ & 220 & 20.66 & 156 & 14.62 & 376 & 35.31 & \multirow[t]{2}{*}{2.} & \multirow[t]{2}{*}{ Middle } & \multirow[t]{2}{*}{175} & \multirow[t]{2}{*}{16.43} \\
\hline 4. & $41-60$ & 100 & 09.39 & 48 & 04.53 & 148 & 13.90 & & & & \\
\hline 5. & $61-80$ & 46 & 04.32 & 16 & 01.51 & 62 & 05.82 & \multirow[t]{2}{*}{3.} & \multirow[t]{2}{*}{ Upper } & \multirow[t]{2}{*}{19} & \multirow[t]{2}{*}{01.78} \\
\hline 6. & $\geq 80$ & 03 & 00.28 & 00 & 00.00 & 03 & 00.28 & & & & \\
\hline \multicolumn{2}{|c|}{ Total } & 677 & 63.57 & 388 & 36.43 & 1065 & 100 & \multicolumn{2}{|c|}{ Total } & 1065 & 100 \\
\hline
\end{tabular}

It is evident from Table No-01 that majority of patients with acute abscesses were male (63.57\%) with male: female ratio was $1.7: 1$. About $80 \%$ patients were under 40 years of age. Most common age group was 21-40 years (35.31\%). Youngest patient was a 9 days old male baby and oldest being an 85 years old male. 
Research Article

Table No 02: Distribution of cases according to site of abscesses, cause, presenting symptoms and signs (n=1065)

\begin{tabular}{|l|l|l|l|l|l|l|l|l|l|}
\hline \multirow{2}{*}{$\begin{array}{l}\text { S. } \\
\text { No }\end{array}$} & \multirow{2}{*}{ Site } & \multicolumn{2}{|c|}{ Total } & \multicolumn{2}{c|}{ Symptoms } & \multicolumn{3}{c|}{ Sign (n=304)-IPD } \\
\cline { 3 - 9 } & & No & $\mathbf{\%}$ & Complaints & No. & $\mathbf{\%}$ & \multicolumn{1}{c|}{ Findings } & No. & \% \\
\hline 1. & Lower limb & 354 & 33.24 & Pain & 1055 & 99.06 & Tachycardia & 139 & 45.72 \\
\hline 2. & Upper limb & 252 & 23.66 & Swelling & 1056 & 99.15 & Pallor & 85 & 27.96 \\
\hline 3. & Thorax & 102 & 09.58 & Fever & 578 & 54.27 & Fever & 42 & 13.82 \\
\hline 4. & Breast & 87 & 08.17 & Discharge & 124 & 11.64 & Sepsis & 15 & 04.93 \\
\hline 5. & Trunk & 87 & 08.17 & Loss of function & 07 & 02.30 & $\begin{array}{l}\text { Regional } \\
\text { Lymphadenopathy }\end{array}$ & 11 & 03.62 \\
\hline 6. & Head \& Neck & 65 & 06.10 & \multicolumn{2}{|c|}{ Cause of Abscesses } & & Tenderness & 304 & 100 \\
\hline 7. & Perineum & 68 & 06.38 & Not known & 847 & 79.53 & Fluctuation & 267 & 87.80 \\
\hline 8. & Multiple & 50 & 04.69 & Trauma & 140 & 13.15 & Skin changes & 283 & 93.12 \\
\hline \multicolumn{2}{|l|}{ Total } & 1065 & 100 & Post injection & 78 & 07.32 & & \\
\hline
\end{tabular}

It is evident from table No-2 that incidence of abscesses were more common in lower limb (33.24\%) with head \& neck being the least common site $(6.10 \%)$. Multiple site abscesses were very rare (4.69\%). Pain and swelling were most common symptoms (99.09\% \& 99.15\% respectively) followed by fever (54.27\%). Tenderness, skin changes (red \& shiny, abscess pointing, dark pigmentation, excoriation \& ulceration) and fluctuation were most common local signs (in $100 \%, 93.12 \%$ \& $87.8 \%$ respectively. Tachycardia and pallor were common systemic findings in $45.72 \%$ and $27.96 \%$ cases. This is also evident that in $79.53 \%$ cases, cause is not known. But this is alarming that $7.32 \%$ (78 patients out of 1065$)$ abscess developed after intramuscular injections. 62 patients had gluteal abscess and 16 patients had abscess over arm.

Table No 03:Pre-hospitalization intervention/ treatment $(n=304)$

\begin{tabular}{|c|c|c|c|c|c|c|}
\hline S. No & Type of intervention & & No. of cases & $\%$ & Total & Grand Total \\
\hline 1. & Application of local remedies & \multirow{3}{*}{$\begin{array}{l}\text { Non-medical } \\
\text { intervention }\end{array}$} & 61 & 20.07 & \multirow{3}{*}{$40.46 \%$} & \multirow{6}{*}{$74.67 \%$} \\
\hline 2. & Hot fomentation & & 50 & 16.45 & & \\
\hline 3. & Massage & & 12 & 03.94 & & \\
\hline 4. & Antibiotics and analgesics & \multirow{3}{*}{$\begin{array}{l}\text { Medical } \\
\text { intervention }\end{array}$} & 58 & 19.08 & \multirow{3}{*}{$34.21 \%$} & \\
\hline 5. & Analgesic only & & 41 & 13.49 & & \\
\hline 6. & Incision and drainage & & 05 & 01.64 & & \\
\hline 7. & No treatment & & 77 & 25.33 & 25.33 & 25.33 \\
\hline \multicolumn{3}{|c|}{ Total } & 304 & 100 & 100 & 100 \\
\hline
\end{tabular}

It is evident from table no-04 that majority of patients (74.68\%) received treatment before admitted to the surgical ward. $34.21 \%$ patients have received medical treatment, most of the from unqualified persons. $40.47 \%$ patients used home remedies (non-medical interventions) to deal abscesses.

Table No 04: Distribution of different laboratories results

\begin{tabular}{|c|c|c|c|c|c|c|c|c|c|c|c|c|}
\hline \multirow{2}{*}{$\begin{array}{l}\text { S. } \\
\text { No. }\end{array}$} & \multicolumn{3}{|c|}{ Hemoglobin (Gm\%) } & \multicolumn{3}{|l|}{ TLC } & \multicolumn{3}{|c|}{ RBS (mg\%) } & \multicolumn{3}{|c|}{ Puss culture } \\
\hline & Range & No & $\%$ & Range & No & $\%$ & Range & No & $\%$ & Result & No & $\%$ \\
\hline 1. & $3-6$ & 04 & 01.92 & $5500-8500$ & 37 & 17.79 & $<130$ & 198 & 81.48 & Positive & 111 & $\begin{array}{l}55.5 \\
5\end{array}$ \\
\hline 2. & $7-10$ & 132 & 63.46 & $8500-11000$ & 75 & 36.06 & $130-160$ & 33 & 13.58 & Negative & 89 & $\begin{array}{l}44.4 \\
5\end{array}$ \\
\hline 3. & $>10$ & 72 & 34.62 & $>11000$ & 96 & 46.15 & $>160$ & 12 & 04.94 & - & - & - \\
\hline Total & & 208 & 100 & & 208 & 100 & & 243 & & & 200 & 100 \\
\hline
\end{tabular}

It is evident from above table that $65.38 \%$ patients of our study were anemic. Total leucocyte count was raised only in $46.15 \%$ cases. Majority of patients $(81.48 \%$ ) were non diabetic, only $4.94 \%$ cases were diabetic, but $13.58 \%$ cases were in pre-diabetic range. This is also evident that 200 randomly selected cases for puss culture, $55.55 \%$ cases were positive for causative organism. 
Research Article

Table No 05: Distribution of culture \& sensitivity of organism $(n=111)$

\begin{tabular}{|l|l|l|l|l|l|l|l|l|l|l|}
\hline $\begin{array}{l}\text { S. } \\
\text { No }\end{array}$ & $\begin{array}{l}\text { Organism } \\
\text { Grown }\end{array}$ & $\begin{array}{l}\text { No of } \\
\text { cases }\end{array}$ & $\%$ & Amikacin & $\begin{array}{l}\text { Genta } \\
\text { micin }\end{array}$ & $\begin{array}{l}\text { Ciprofl } \\
\text { oxacin }\end{array}$ & $\begin{array}{l}\text { Ceftri } \\
\text { axone }\end{array}$ & $\begin{array}{l}\text { Cefur } \\
\text { oxime }\end{array}$ & $\begin{array}{l}\text { Cefota } \\
\text { xime }\end{array}$ & $\begin{array}{l}\text { Clarithr } \\
\text { omicin }\end{array}$ \\
\hline 1. & $\begin{array}{l}\text { Staphylococcu } \\
\text { s aureus }\end{array}$ & 80 & 72 & 93.7 & 81.0 & 50.0 & 84.3 & 87.5 & 55.0 & 82.5 \\
\hline 2. & $\begin{array}{l}\text { Klebsiella } \\
\text { aeruginosa }\end{array}$ & 12 & 11 & 91.0 & 83.0 & 25.0 & 83.0 & 50.0 & 50.0 & 75.0 \\
\hline 3. & E. coli & 10 & 09 & 70.0 & 90.0 & 80.0 & 70.0 & 70.0 & 70.0 & 80.0 \\
\hline 4. & Pseudomonas & 09 & 08 & 78.0 & 66.0 & 20.0 & 67.0 & 55.0 & 55.0 & 66.0 \\
\hline
\end{tabular}

It is evident from Table No-05 that staphylococcus aureus was the most common organism cultured in $72 \%$ ( 80 out of 111 positive cultured) of samples. Klebsiella aeruginosa, E. coli and pseudomonas were the other common organism, cultured in $11 \%, 09 \%$ and $08 \%$ of samples. Staphylococcus aureus was highly sensitive to amikacin, cefuroxime and ceftriaxone (93.7\%, 87.5\% and 84.3\%), Klebsiella was highly sensitive to amikacin \& ceftriaxone (91\% and $83 \%$ ), pseudomonas was highly sensitive to amikacin \& ceftriaxone (78\% and 67\%) and E. coli was sensitive to gentamicin \& ciprofloxacin (90\% and $80 \%$ respectively).

Majority of patients (61.51\%) shown good result after I\&D along with proper antibiotic coverage and discharged within 7 days. There is delay in healing with few patients (28.95\%) and discharge after 2 weeks only. 9.54\% patients shown poor healing and needed prolong stay and antibiotics course usually more than 3 weeks. These patients had some underling disorders.

\section{Discussion}

Acute abscesses are one of the common surgical emergencies. A wide range of acute abscesses occurs in tropical environment like India and is an important cause of morbidity. An abscess is a tender mass generally surrounded by a colored area from pink to deep red. Abscesses occur when an area of tissue becomes infected and body is able to wall off the infection to keep it from spreading. Abscesses are often easy to feel by touching, the middle of an abscess is full of pus and debris, painful and warm to touch. Abscesses can show up any place on our body.

The most common sites are axilla, gluteal region, groin areas, around anus and vagina (i.e. Bartholin gland abscess), the base of spine (pilonidal abscess) and around a tooth (dental abscess). Inflammation around a hair follicle can also lead to the formation of an abscess, which is called a boil (furuncle).

People with weakened immune systems, [chronic steroid therapy, chemotherapy, diabetes, cancer, AIDS, sickle cell disease, leukemia, peripheral vascular disorders, crohn's disease, ulcerative colitis, severe burns, severe trauma and alcoholism or IV drug abuse], get certain abscesses more often and more severe. This is because the body has a decreased ability to ward off infections. Unlike other infections, antibiotics alone will not usually cure an abscess. In general an abscess must open and drain in order for it to

improve. Sometimes draining occurs on its own, but generally it must be opened by a doctor especially surgeon, in a procedure called incision and drainage (I\&D). A total of 1065 cases were studied in our study, which probably represent an underestimation, as may reflect difficulties in accessing health care for functional, geographic, socioeconomic and cultural reasons.

Most of serious skin infections were preceded by an identified or unidentified skin injury. This could be related to the warmer climate. Increased environmental air temperature has been linked to higher frequencies of insect bites and subsequent rises in impetigo incidence. In addition, increased skin exposure due to individual, socioeconomic and climatic factors may raise the rate of both insect bites and other minor skin injuries [11].

As diagnosis of soft tissue abscess was primarily based on clinical signs and symptoms, with infrequent need for any investigations beyond basic hematology, biochemistry and microbiological testing. These tests were necessary for diagnosis of associated medical illness. 
In our study prevalence of acute abscesses was more in patients under 40 years of age $(80 \%)$ and male patients were more than females $(63.57 \%$ Vs $36.43 \%)$. This may be because, in our culture males are the working members and females are usually housewife; moreover majority of laborers, field workers and farmers were males and they were more prone for trauma and insect bite. On the other hand, males are also given preference over females, in utilization of health services. Other studies, Stewart et al (1985) also favor male predominance with male: female ratio $2: 1$ [11].

Incidence of acute abscesses was more common in lower socio-economic group $(81.78 \%)$. It is mainly due to their poor living standard, poor personal hygiene, poor nutritional status, illiteracy and ignorance regarding various aspects of illness as well as its treatment.

The lower limb is the most commonly affected sites (33.24\%) in our study. Other authors also have reported a predominance of lower limb $[12,13,22]$. Reason for this is likely to be a result of frequent minor trauma to the legs. Old age diseases like atherosclerosis and Buerger's disease may also predispose to lower limb abscesses after minor injuries.

In the current study predisposing factor for abscess formation was found in 218 patients $(20.47 \%)$. Out of these $78(7.32 \%)$ patients had abscess following intramuscular injection, 140 (13.15\%) after blunt trauma. Injection abscesses were more common in gluteal region compare to arm region $(79.49 \%$ Vs $20.51 \%)$. The high association of gluteal abscesses with intramuscular injections indicates that aseptic techniques were probably not followed by unqualified and even qualified health care professionals.

Intramuscular injection even with the use of disposable syringe can lead to abscess formation [7, 8] and the mechanism of infection has been reported as tissue damage followed by endogenous (hematogenous) infection. Exogenous infection can also occur in penetrating trauma.

Use of improper drug at improper sites, without taking due precautions by medical and paramedical persons at all level of health care system, has increased the post injection abscesses. These injection abscesses were converted into a large deep seated abscess in patients who received massage and hot fomentation after intramuscular injection to get relief pain. Maqbool S et al (1999) and many other authors also reports trauma as a cause of abscesses in $25 \%$ patient $[4,5,6]$.
In our study majority of patients were illiterate, poor and residing far away from health centers. They waited for the abscesses to ripen (i.e., when skin became yellow) and only after that they came for the treatment. Most of the patients received different type of premedication in the form of hot fomentation, local application of various types of leaves and poultices of methi dana, lime, turmeric, honey, tulsi alone or in combination with different oils eg-noorani tel, bijli ka tel, mustard oil with or without massage, before they seek medical advice.

All these intervention caused various changes like dark skin pigmentation, excoriation, thinned black skin leading to poor healing and bad cosmetic. Massage therapy over abscess and infected area should be avoided, as massage could spread the infection [23].

Most complementary medical interventions, including massage therapy, are dangerous until all signs of a cellulitis infection have dissipated. Massage is contraindicated in the treatment of patients with malignancy, acute inflammation or closed abscesses, and those who are in the third trimester of pregnancy. Effect of use of these home remedies is not available in medical literature. We need a dedicated study to see effect of these home remedies.

Lab investigations were done in limited patients because of economic limitations and un-willingness by the patients. Anemia is a known to be a predisposing factor that lowers resistance to infection [3]. This was confirmed by the presented data of $65.38 \%$ of patients having moderate to severe anemia. In the current study, culture was done in 200 randomly selected patients and reports were positive in $55.55 \%$ cases while in $44.45 \%$ no organism was cultured.

This high rate of culture negative may be because many of these patients were already on antibiotic therapy before coming to us. The organism most commonly involved were Staphylococcus aureus and Klebsiella aeruginosa in $72 \%$ and $11 \%$ cases respectively. These finding are supported by other studies which identified $S$. aureus as being the major organism in cutaneous abscesses $[9,14,15,19]$.

All these organisms showed predictable sensitivity to standard antibiotics such as ceftriaxone, amikacin, cefuroxime, gentamicin and clarithromycin and metronidazole for anaerobes. A significant number of patients had been started postoperative antibiotics. Incision and drainage of abscesses is usually adequate treatment. 
Majority of patients (61.51\%) have shown good result, symptoms subside within 5 days and discharge within 7 days of admission. In $28.95 \%$ symptoms relieved within two weeks and required admission $\geq 2$ weeks of admission. Few patients have poor response, symptoms persist for $\geq 2$ weeks, required re-drain and only discharge after 3 weeks.

Poor responders usually had underling pre-existing disorders like severe anemia, uncontrolled diabetes, chronic malnutrition etc. Mortality is rare and usually due to an underlying disease condition, HIV and neglect.

Controversy exists about the use of antibiotic therapy following incision and drainage of cutaneous abscess. Few studies conclude that antibiotics did not alter the outcome of superficial Abscess [10]. They also advise that routine culture and antibiotic therapy were not indicated for localized abscesses in patients with normal host defenses. On the other hands some studies advocate that parenteral antibiotic treatment diminished the rate of bacteremia, when used before draining subcutaneous abscess.

In developing countries like India, where anemia and malnutrition are very common, unhygienic condition and poor health facilities, it seemed more prudent to give antibiotic. Appropriate antibiotic therapy is the key to infection treatment. Empirical therapy should depend on several factors, like potential pathogens, disease severity, clinical complications and the instrument of entry (eg, animal bite). For all uncomplicated lesions, empirical therapy should target the typical Gram-positive skin flora, such as Staphylococcus aureus [17,18,20].

\section{Conclusion}

Abscesses and other soft tissue infections represent a significant burden on health care system. There is a high frequency of soft tissue infections in developing countries like India. Many of these abscesses follow trauma including intra-muscular injections.

Use of different type of premedication in the form of hot fomentation, local application of various types of leaves and poultices and massage can increase complication. Improving living standard, early presentation and treatment can reduced the incidence, morbidity and mortality from acute abscesses in our environment. Education regarding proper use of sterilized needles by staff and technician and early initiation of adequate treatment of cellulitis should be done to prevent complications.

\section{Funding: Nil \\ Conflict of interest: Nil \\ Permission from IRB: Yes}

\section{References}

1. Kakar N, Kumar V, Mehta G, Sharma RC, Koranne RV. Clinico-bacteriological study of pyodermas in children. J Dermatol 1999 May; 26(5): 288-93.

2. Bundred NJ, Dover MS, Coley S, Morrisom JN. Breast abscess and cigarette smoking. Br J Surg. 1992;79:58-60.

3. Keusch G T. Micronutrients and susceptibility to infection. Annals of the New York Academy of Sciences. 1990; 1587: 1181-88.

4. Anatol T I. Soft tissue infection in children in South Trinidad West Indian Med J 1992; 41(1): 27-30.

5. Ajao O G, Ajao A O. Tropical pyomyositis Int Surg 1982; 67(4): 414-6.

6. Maqbool S, Razaque S. Pediatric outpatient department -experience of 5 years; Pak Paed J 1999; 23(2): 57-60.

7. Ahmed M E, Fahal A H. Acute gluteal abscesses: injectable chloroquine as a cause. J Trop Med Hyg 1989; 92(5): 317-9.

8. Zhadinskii N V, Kondratenko G P, Rudenko A A. Mechanism of the occurrence of postinjection abscesses. Zh Mikrobiol Epidemiol Immunobiol 1989; 1(1): 80-3.

9. Khan J S, Khan J A, Hassan H, Bhopal F G, Iqbal M. Surgical audit of skin and soft tissue infections J Rawal Med Coll 2005; 9(1): 26-9.

10. Llera J L, Levy R C. Treatment of cutaneous abscess: a double-blind clinical study Ann Emerg Med 1985; 14(1): 15-9.

11. Elliot AJ, Cross KW, Smith GE, et al. The association between impetigo, insect bites and air temperature: A retrospective 5-year study (1999-2003) using morbidity data collected from a sentinel general practice network database. Fam Pract. 2006;23:490-496.

12. Kristensen JK. Scabies and pyoderma in Lilongwe, Malawi. Prevalence and seasonal fluctuation. Int $\mathrm{J}$ Dermatol. 1991;30:699-702. 
13. Masawe A, Nsanzumuhire H, Mhalu F. Bacterial skin infections in preschool and school children in costal Tanzania. Arch Derm. 1975;111:1312-6.

14. Mandal R, Banerjee AR, Biswas MC, Mondal A, Kundu PK, Sasmal NK. Clinicobacteriological study of chronic dacryocystitis in adults. J Indian Med Assoc. 2008 May;106(5):296-8.

15. Abbas TO. Pelvic primary staphylococcal infection presenting as a thigh abscess. Case Rep Surg.2013; 2013:539737.

16. $\mathrm{Ki} \mathrm{V}$, Rotstein C. Bacterial skin and soft tissue infections in adults: A review of their epidemiology, pathogenesis, diagnosis, treatment and site of care. Can J Infect Dis Med Microbiol. Mar 2008; 19(2): 173-184.

17. Stevens DL, Bisno AL, Chambers HF, et al. Infectious Diseases Society of America. Practice guidelines for the diagnosis and management of skin and soft-tissue infections. Clin Infect Dis. 2005;41:1373-406.

18. Elston DM. Optimal antibacterial treatment of uncomplicated skin and skin structure infections:
Applying a novel treatment algorithm. J Drugs Dermatol. 2005;4(6 Suppl):s15-9

19. Hook EW, III, Hooton TM, Horton CA, Coyle MB, Ramsey PG, Turck M. Microbiologic evaluation of cutaneous cellulitis in adults. Arch Intern Med. 1986;146:295-7.

20. Fung HB, Chang JY, Kuczynski S. A practical guide to the treatment of complicated skin and soft tissue infections. Drugs. 2003;63:1459-80.

21. Stewart MPM, Laing MR, Krukowski ZH. Treatment of acute abscesses by incision, curettage and primary suture without antibiotics: A controlled clinical trial. Br J Surg. 1985 Jan; 72 (10):66-7.

22. Elliott DC, Kufera JA, Myers RA. Necrotizing soft tissue infections. Risk factors for mortality and strategies for management. Ann Surg. 1996 Nov; 224(5): 672-83.

23. Newton, Don D.C. Clinical Pathology for the Professional Bodyworker. Scappoose, Ore.: Simran Publications: 1998: 182-194.

\section{How to cite this article?}

Patel VK, Patel U, Gaharwar APS, Shrivastava GP, Gupta R, Patel NP. Clinico-Bacteriological profile \& Effect of Home remedies on Acute Abscess. Int J Med Res Rev 2014;2(5):428- 434. doi:10.17511/ijmrr.2014.i05.05 